\title{
The role of renewable energy policies for carbon neutrality in Helsinki Metropolitan area
}

\section{Dahal, Karna}

2018-07

Dahal , K, Juhola , S \& Niemelä , J 2018 , ' The role of renewable energy policies for carbon neutrality in Helsinki Metropolitan area ', Sustainable Cities and Society, vol. 40 , pp.

222-232 . https://doi.org/10.1016/j.scs.2018.04.015

http://hdl.handle.net/10138/313960

https://doi.org/10.1016/j.scs.2018.04.015

cc_by_nc_nd

acceptedVersion

Downloaded from Helda, University of Helsinki institutional repository.

This is an electronic reprint of the original article.

This reprint may differ from the original in pagination and typographic detail.

Please cite the original version. 


\section{Accepted Manuscript}

Title: The role of renewable energy policies for carbon neutrality in Helsinki Metropolitan area

Authors: Karna Dahal, Sirkku Juhola, Jari Niemelä

PII: $\quad$ S2210-6707(18)30053-2

DOI: $\quad$ https://doi.org/10.1016/j.scs.2018.04.015

Reference: $\quad$ SCS 1055

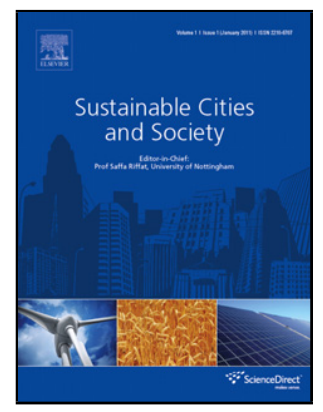

To appear in:

Received date: $\quad 9-1-2018$

Revised date: $\quad 9-4-2018$

Accepted date: $\quad 9-4-2018$

Please cite this article as: Dahal, Karna., Juhola, Sirkku., \& Niemelä, Jari., The role of renewable energy policies for carbon neutrality in Helsinki Metropolitan area.Sustainable Cities and Society https://doi.org/10.1016/j.scs.2018.04.015

This is a PDF file of an unedited manuscript that has been accepted for publication. As a service to our customers we are providing this early version of the manuscript. The manuscript will undergo copyediting, typesetting, and review of the resulting proof before it is published in its final form. Please note that during the production process errors may be discovered which could affect the content, and all legal disclaimers that apply to the journal pertain. 


\author{
Article
}

The role of renewable energy policies for carbon neutrality in Helsinki Metropolitan area

\title{
Karna Dahal ${ }^{1 *}$, Sirkku Juhola ${ }^{2}$ and Jari Niemelä ${ }^{3,}$
}

1 Department of Environmental Sciences, University of Helsinki, P.O. Box 65, Viikinkaari 2, FI-00014 Helsinki, Finland. karna.dahal@helsinki.fi

2 Department of Environmental Sciences, University of Helsinki, P.O. Box 65, Viikinkaari 2, FI-00014 Helsinki, Finland. sirkku.juhola@helsinki.fi;

3 Helsinki Institute of Sustainability Science, P.O. Box 65, Viikinkaari 2, FI-00014 Helsinki, Finland. jari.niemela@helsinki.fi

* Correspondence: karna.dahal@helsinki.fi; Tel.: +358-44-5131755

\section{Highlights}

- Approximately $8.3 \%$ and $13.3 \%$ renewable share in final heating and electricity consumption in Helsinki Metropolitan area

- Clean and renewable energy production target for energy transition to carbon neutrality

- Policies for integrating renewable energy (waste heat, heat pumps, solar) in the buildings and district heat network

- Several organizational, technological, economic and societal barriers to formulate and implement the renewable energy policies

- The renewable energy policies associated to five different socio-technical regimes

- Innovative policy solutions to overcome the shortcomings and barriers 


\begin{abstract}
Renewable energy policies are necessary for achieving carbon neutrality which is the main goal for climate change mitigation. The cities in the Helsinki Metropolitan area have committed themselves to significantly reducing carbon emissions through various climate measures including some measures for renewable energy utilization. We use multilevel perspective (MLP) and renewable energy frameworks to examine the role of renewable energy policies to carbon neutrality in the Helsinki Metropolitan area and base our analysis on various policy documents and semi-structured interviews. Our findings show that current renewable energy policies in the Helsinki Metropolitan area are weak and many challenges exist. Nevertheless, many options are available for improving existing policies. The cities have many opportunities to adopt various energy policy measures, including small-scale renewable energy production in building premises, renewable energy integration to district heating, demand-side solutions for energy utilization, and increasing budgets and subsidies to renewable energy production and enhancement of the social acceptance of renewable energy. Such additional policies are needed to reach carbon neutrality in the Helsinki Metropolitan area.
\end{abstract}

Key Words: renewable energy, carbon neutrality, energy transition, energy policies

\title{
1. Introduction
}

Low-carbon transitions are long-term multi-faceted processes, consisting of three different approaches; 1) concerns about the climate change impact of the energy production and use, often understood as de-carbonization and carbon neutrality of the energy system; 2) energy security, physical availability of energy in an area; and 3) affordability of energy for residents and commercial use (Hiteva, 2013). Carbon neutrality is an aim for low carbon transition (Brandt et al., 2014). As being one of the pillars of national prosperity, energy policies should be formulated and implemented to ensure the energy security of the region and minimize negative effects on the environment.

Renewable energy and energy efficiency are central components of a successful global low-carbon transition but they will need to be accompanied by other low-carbon technologies, according to each country's circumstances, including energy sector 
potentials, and policy and technology priorities (IEA \& IRENA, 2017; Poggi, Firmino, \& Amado, 2017). A few major transition paths, such as socio-technological, infrastructural and technological, and institutional transitions play an important role in low carbon energy transitions (Verbong \& Geels, 2007). These transition paths are technical, regulatory, and cultural driven by businesses, central and local governments, various institutions and the civil society (Laes, Gorissen, \& Nevens, 2014). Energy transition of the socio-technological path includes end-point energy use and technological changes, due to the social circumstances and consumer choices. Infrastructural and technological transition include changes to physical infrastructures for low carbon energy production, distribution and utilization and low carbon transportation systems. Similarly, institutional factors include development of various policy processes, co-ordinations, and development of knowledge strengthening programs.

The role of cities in reducing global carbon emissions and transforming energy system is essential (Petersen, 2016). The national climate and energy policies are key drivers for the cities' energy and climate policies (Corfee-Morlot et al., 2009) and the transition of energy systems not only includes profound changes to energy technologies but also to social, regulatory, and economic aspects of energy production, supply, and consumption (Miller, Iles, \& Jones, 2013). It is also crucial to understand the present energy investment landscape and how it can evolve to meet the carbon neutrality goals and to contribute to low carbon energy transition (IEA \& IRENA, 2017). Thus, integration of social issues, such as policy processes and investment decisions and robust short and long-term policy implications, will be needed in the transition processes (Laes, Gorissen, \& Nevens, 2014; Voß, Smith, \& Grin, 2009; Nevens \& Roorda, 2013).

The cities in the Helsinki Metropolitan area have committed themselves to carbon neutrality (Dahal \& Niemelä, 2016). They have been deploying both the national as well as local renewable energy policies and set several renewable energy policy targets for carbon neutrality. However, the role of such national and local level energy policies and renewable energy policies on carbon neutrality in the Helsinki Metropolitan area have not been studied yet. Furthermore, it is not known to what extent these (renewable) energy policies are formulated and implemented and if there are any shortcomings of the existed renewable policies in the cities in the Helsinki Metropolitan area. The main questions we address in this paper are: 
1. How have the local and national (renewable) energy policies been deployed in the cities in Helsinki Metropolitan area?

2. What are the shortcomings of existing renewable energy policies and barriers for implementing such policies in this area?

We also explore some solutions for the implementation of renewable energy policies in the case area. In addition, this paper also contributes to our understanding of city level renewable energy generation, distribution, integration policies as such energy policies have great impact on the renewable energy promotion and integrated energy development, as well as carbon neutrality.

In section 2, we explain the background of the concepts of energy transition for carbon neutrality and the chosen analytical framework. In section 3, we outline the materials and methods used in this study. Section 4 presents the results, including the multidimensional prospects of, renewable energy policies for low carbon energy transition. Finally, in section 5, we discuss the outcomes and present our concluding remarks.

\section{Analytical framework and methodology}

\subsection{The role of energy transition to accomplishing carbon neutrality}

Over the past years, low carbon energy transition has been at the core of climate policies in many countries and cities (Brandt et al., 2014). Carbon neutrality means balancing artificial carbon emissions by offsetting with various emission reduction activities and low carbon energy production methods to obtain net zero carbon footprint (Dahal \& Niemelä, 2016). The energy transition needed to reach carbon neutrality is vital at production stage of carbon emissions and energy policies applied at this stage determine the quantity of reduced carbon emission. The energy policies become even more important when the energy induced carbon emissions cover a big part of the total carbon emissions production of a city or a country.

Transition to renewable energy depends on various factors, such as energy policies, abundancy and feasibility of energy sources, business models, prices for renewables vs. fossil fuels, energy security, and attitudes towards the new energy sources. Renewable 
energy policies are key to achieving carbon neutrality because renewable energy sources are everlasting and produce negligible carbon during their lifecycles (Aslani, Helo, \& Naaranoja, 2013; Singh, Pant, \& Olsen, 2013). Most of them are abundantly available all over the world (Timmons, Harris, \& Roach, 2014). Energy production from wind and solar have become popular in many European countries while geothermal production has been the pioneering heating solution in the cold climatic regions (Minea, 2015). Similarly, hydropower production potential from run-off water is significant but related environmental issues need to be taken into consideration. Many scientists also agree that bioenergy is beneficial for low carbon energy solutions in the regions where its' abundance is high (Puigjaner, Pérez-Fortes, \& Laínez-Aguirre, 2015). Energy production from bioenergy can be the easiest way to low carbon energy solutions in the various regions, such as Finland, where massive ( $80 \%$ of total renewables) wood-based energy is produced using by-products and residues from the forest industry (Korhonen, et.al., 2015). If these renewable energy sources are utilized and manipulated sustainably, significant carbon emissions can be reduced and energy transition to carbon neutrality is achieved (IEA, 2009; Owusu \& Asumadu-Sarkodie, 2016).

The economic factors for a transition towards renewables are currently moving in the right direction towards carbon neutrality (Timmons, Harris, \& Roach, 2014). Low carbon innovation market is changing rapidly, as the costs of renewable energy and transportation technologies are decreasing (Nykvist \& Nilsson, 2015). Furthermore, latest innovations such as smart meters, hybrid vehicles, and building automation systems will reduce the cost of low carbon technologies, lowering the gains from fossil fuels. Renewable energy production and storage technologies are potentially disruptive because they alter the way we produce and use energy and create new business ecosystems, leading to radical shifts in the roles of consumers and service providers (Manyika et al., 2013). Certain renewable energy sources (e.g. solar) are already competing with fossil fuels solely on financial terms in some countries (Timmons, Harris, $\&$ Roach, 2014). Wind power production prices have also declined over the last 10 years (Taylor, Ralon, \& Ilas, 2016). These developments are encouraging factors for energy transition which the cities in Helsinki Metropolitan area are also benefiting from it to achieve carbon neutral goals. 
Several cities are aiming to achieve carbon neutrality by importing low-carbon energy and employing nuclear energy from other regions in addition to carbon emissions reductions from sources and sinks (Dahal \& Niemelä, 2017; Sovacool, 2017). However, real carbon emissions are not reduced in the cities' geographical boundaries if imported low carbon energy is counted in the carbon neutral goal. In addition, nuclear energy also has several concerns on the safety issues which retards the overall sustainability of the carbon neutral strategy (Kyne \& Bolin, 2016).

\subsection{Approaches to carbon neutrality and renewable energy policies in Helsinki Metropolitan area and Finland}

The cities in Helsinki Metropolitan area have set individual goals to become carbon neutral in addition to the Helsinki Region Environmental Services Authority (HSY)'s vision of a carbon neutral Helsinki Metropolitan area by 2050 (Dahal \& Niemelä, 2016). Previously, the City of Helsinki and Espoo had set goals to become carbon neutral by 2050 but they are currently working on more ambitious carbon neutrality targets. Helsinki city council has passed a bill to become carbon neutral already by 2035 and the Espoo has passed a climate strategy to become carbon neutral by 2030. The cities have defined their approaches for reaching the goal differently. Helsinki aims to reduce total carbon emissions by $80 \%$ by 2035 and the remaining $20 \%$ will be reduced with other means. Espoo has not defined how to achieve carbon neutrality. Vantaa has committed itself to reducing $80 \%$ of total emissions by 2050 while the City of Kauniainen, a very small city, does not have any specific targets. Actions towards carbon neutrality are happening in the Helsinki Metropolitan area (Dahal \& Niemelä, 2016) but renewable energy strategies are not clearly stated in the cities' climate strategies. Only Helsinki has defined the share of renewable energy which it will include in its final energy consumption (Dahal, Niemelä, \& Juhola, 2017).

At the national level, Finland's long-term climate strategy is to become carbon neutral by 2050 (Parliamentary Committee on Energy and Climate, 2014). There is an ambitious renewable energy target to increase the share of renewable energy to 38\% of final energy consumption by 2020 (IEA, 2013; Aslani, Helo, \& Naaranoja, 2013). In 2016, the country achieved $34 \%$ renewable energy share in its final energy consumption (Tilastokeskus, 2017). While the national level renewable energy target will most likely be achieved, 
Helsinki Metropolitan area is struggling to achieving $20 \%$ renewable energy target by 2020. This target is the same as at the EU level but about half of the national level target. Currently, Helsinki Metropolitan area has approximately 8.3\% renewable share in its final heating consumption and $13.3 \%$ in its final electricity consumption (Helsinki Environmental Statistics, 2017; Dahal \& Niemelä, 2016). Today, fossil fuels-coal and natural gas - are the dominant energy source in the Helsinki Metropolitan area (Dahal \& Niemelä, 2016; Aslani, Helo, \& Naaranoja, 2013).

\subsection{A framework of renewable energy policies for carbon neutrality}

Since the renewable energy policies are the major mechanism for carbon neutrality, they need to be carefully formulated and implemented. The framework in Figure 1 helps to understand the stages for formulation and implementation of renewable energy policies. This links to study of socio-technical transition at the level of entire energy system described in section 2.4 as the framework refers to tangible and measurable elements, such as infrastructures, market values, regulations, consumption patterns and public opinion. The figure represents the types of major renewable energy policies applicable for carbon neutrality at the national, as well as the local level. Renewable energy policies usually include the policies from energy production through energy conservation and energy distribution to energy utilization (Hiteva, 2013). The major policy components of the framework for renewable policies represent four different types in a box, which are further categorized.

\begin{tabular}{|c|c|}
\hline $\begin{array}{l}\text { Energy Production } \\
\text { - } \quad \text { Production methods } \\
\text { - } \text { Fuel shifting } \\
\text { - } \text { Renewable energy use } \\
\text { - }\end{array}$ & 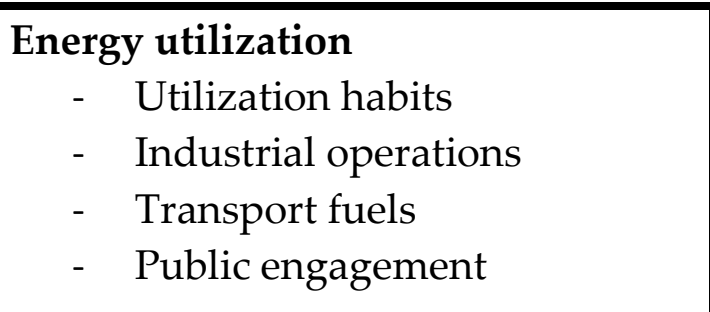 \\
\hline $\begin{aligned} & \text { Energy Distribution } \\
&- \text { Intelligent grids } \\
&- \text { Storage technology } \\
&- \text { Renewable integration } \\
&- \text { Energy markets }\end{aligned}$ & $\begin{aligned} & \text { Energy Conservation } \\
& \text { - } \text { Electric vehicles } \\
&- \text { Energy efficiency } \\
& \text { improvements } \\
&- \text { Energy consumption practices } \\
& \text { - } \text { Demand solutions }\end{aligned}$ \\
\hline
\end{tabular}

Figure 1: Framework for renewable energy policies 
Policies related to energy production are energy production methods in the power plants or energy producing sites, shifting of fuels from fossil fuels to clean and renewable fuels, and deployment of the renewable energy sources (Figure 1). Policies for the energy utilization are related to how the consumers utilize the energy for daily use, what fuels are used for industrial operations and how they are performed, and what kind of fuels are used in vehicles or whether the vehicles are modified for the clean fuel use. Policies required for energy conservation are the development of storage technologies, boosting electric vehicle use, and increasing research and development projects for such technologies. Renewable energy integration policies are important for end energy usage across the energy distribution network, such as small-scale electricity integration to electricity grids and heat pumps and other renewable energy (e.g. solar, geothermal and waste heat) integration to district heating (DH) network. In addition, energy consumption reduction policies between the energy conservation to energy utilization phase are also important for the sustainable utilization of renewable energy. For instance, demand side solutions policies, such as smart metering, thermostat settings, and waste heat recovery systems etc. We use this framework for analyzing the data in section 4.1.

\subsection{Multi-level perspective on socio-technical transition of the energy systems}

Energy transitions to carbon neutrality concern the interactions between technology, policies, businesses and society. It is a multidimensional process with potential lock-ins with the existing structures of financial, institutional, and infrastructure systems (Geels, 2011). Such structures are subjected to change with various socio-technical transition practices, such as technology, policy, markets, consumer practices, cultural meaning and scientific knowledge (Geels, 2011). A multi-level perspective (MLP) can be used to understand the multi-dimensional nature of energy transition and dynamics of structural changes for achieving carbon neutrality in the city level. The MLP not only focuses on upstream green electricity production technologies (e.g. wind, solar, bio-energy) but also broader socio-technical innovations, such as the civil society and cities' initiatives (Geels, 2014). The MLP of the entire energy system is formed from the interplay of developments at three analytical levels: socio-technical regimes, socio-technical landscapes, and niches (Kivimaa \& Kern, 2016). Figure 2 depicts the MLP of energy transition for the cities. 
Activities in local practices

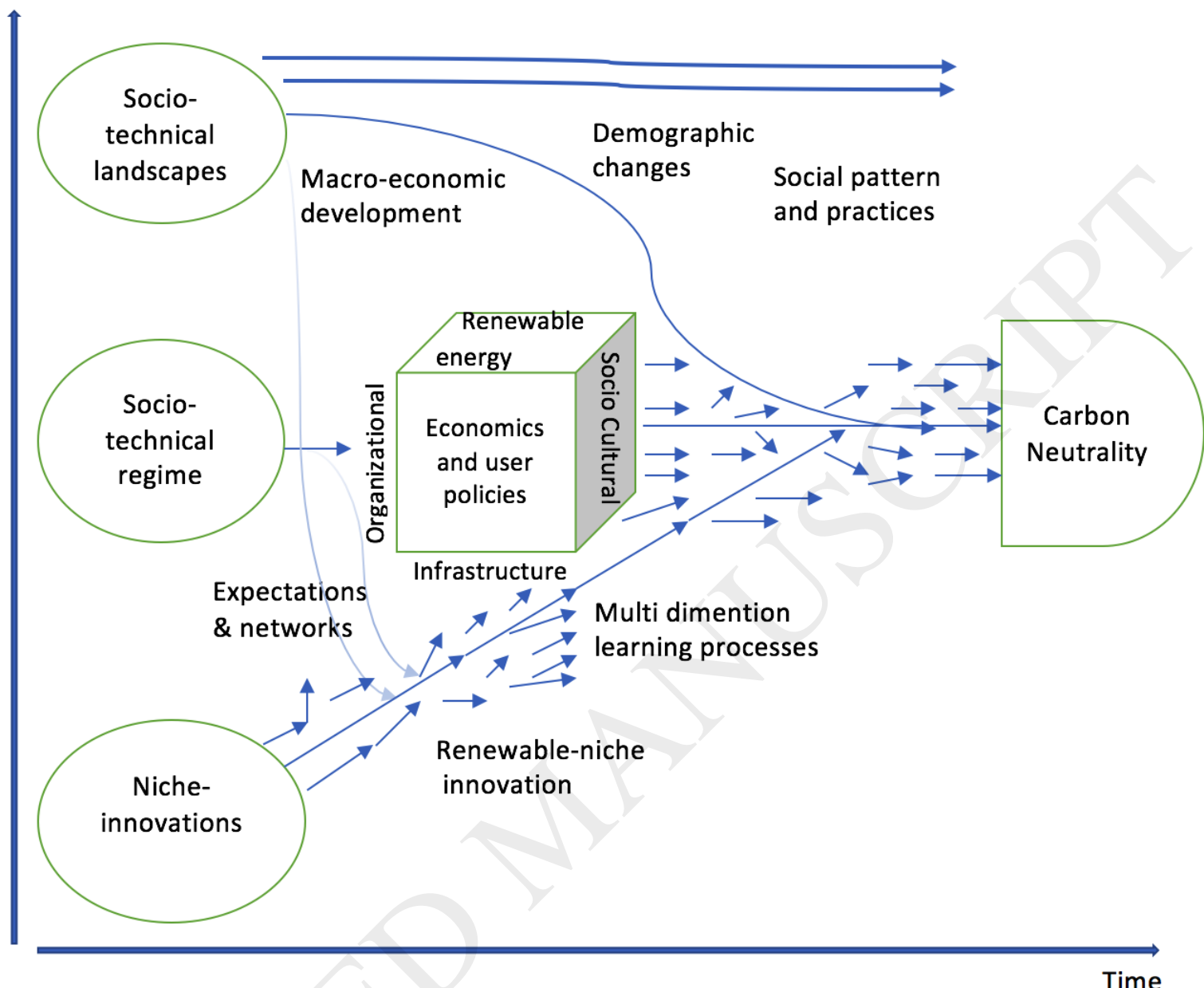

Figure 2: Multi-level perspective on socio-technical transition of the energy systems (adapted from Geels, 2011)

Socio-technical regimes include various regime rules. The hexagon within the transition framework is a multi-faceted renewable energy policy regime interface with five different socio-technical regimes, including renewable energy, organizational, infrastructure, market and user policies and socio-cultural. The arrows directed towards carbon neutrality indicate the multi processes of achieving carbon neutrality and other arrows indicate the interrelation between three analytical levels within the socio-technical transition. The MLP is the main analytical framework of this study, focusing on the regime interfaces. In addition, the socio-technical regime includes energy policies for energy production, consumption, distribution, and conservation represented in Figure 2. Thus, both the renewable energy framework and MLP framework are interrelated to addresses the policy processes in the cities. 
In addition to regimes, we pay attention to niches which are 'protected spaces' such as R\&D laboratories, subsidized demonstration projects, or small-scale market which are used in regime dynamics (Geels, 2011). They support the emerging innovations and promote renewable energy, which provides the bases for energy transition to carbon neutrality. This study focuses on the renewable niche innovation in the Helsinki Metropolitan area as the cities' renewable innovation and market policies are vital for promoting renewable energy and carbon neutrality.

\section{Material and Methods}

The Helsinki Metropolitan area was chosen for the study of the renewable energy policies as the cities in this area utilize a low proportion of renewable energy of the total energy production? in comparison to other parts of the country. We gathered information on national policies and local policies for renewable energy through document analyses and reviews of published documents and through fourteen, an hour long, semi-structured interviews with energy and climate experts and stakeholders in the Helsinki Metropolitan area [an energy planner from ministry of economic and employment (1 person), senior executives from government's energy administrations (3), cities' energy and climate experts (5), environmental organizations (2), an expert from a non-profit smart clean foundation (1) and industrial energy managers (2)]. These experts were selected for their knowledge of national and of local level climate and energy policy contexts. Three of the seventeen people invited did not respond.

The semi-structured interviews consisted of several key questions that help to define the areas to be explored, but also allow the interviewer or interviewee to diverge and pursue an idea or response in more detail (Gill et al., 2008). In comparison to structured interviews, this method also allows flexibility on the expansion of information to participants that may not have been previously thought of by the interview team (Gill et al., 2008). Two different types of information were gathered from the interviews: a) ongoing activities toward carbon neutral in relation to national renewable energy policies and b) barriers and shortcomings of these renewable energy and climate policies for carbon neutrality. Interviews were conducted between August and October 2017. The names of interviewees and some organizational information related to data were kept confidential. 
Document analysis is a form of qualitative research in which texts are interpreted by the researcher to provide robust understanding around an assessment topic (Glenn, 2009). It also incorporates coding content into themes similar to how interview transcripts are analyzed (Glenn, 2009). Document analysis helped to supplement data from the semistructured interviews and document analysis included the review of secondary literature, including policy documents, climate strategy plans and proposals, reports, and press releases issued by various stakeholders, academic papers, and articles from the local online medias (Yle news and Helsinki Sanomat). We coded these materials into different categories based on the goal of the research and contents in the relevant documents and analyzed to compare the respondents' viewpoints on:

- Finland's renewable energy policies for low carbon energy transition and carbon neutrality

- Helsinki Metropolitan cities' renewable energy policies for carbon neutrality

- Awareness and promotional activities for renewable energy in Helsinki Metropolitan area

- Financial measures and stakeholder engagements for the renewable energy development

- Cities' carbon neutral activities and plans in the Helsinki Metropolitan area We used the renewable energy policy framework (Figure 1) and multi-level perspective (MLP) framework (Figure 2) to analyze the data (see Results section). Renewable energy policy framework was used (in section 4.1) to understand the renewable energy policies both in Finland and Helsinki Metropolitan area. Similarly, multi-level perspective (MLP) framework was used to analyze the socio-technical transition of the energy systems (in section 4.2). We focused mainly on five components of the socio-technical regime and one component of niche levels of the MLP framework. The five components of the sociotechnical regime were: a) renewable energy dynamics, b) organizational dynamics, c) infrastructure dynamics, d) economics and user policies dynamics, and e) socio-cultural dynamics.

\section{Results}

\subsection{National and local level renewable energy policies for carbon neutrality}


Clean and renewable energy production is one major target for energy transition to carbon neutrality. Table 1 presents several energy policies for renewable energy production at both the national level and the City of Helsinki. Some of the energy policies of the City are at proposal stage and they are not binding policies yet.

Table 1: Policies for energy production in Finland and Helsinki Metropolitan area (Ministry of economic affairs and employment, 2017; Helsingin kaupungin ympäristokeskus, 2015; Huuska et al., 2017; Parliamentary Committee on Energy and Climate, 2014)

\begin{tabular}{|c|c|}
\hline & litan area \\
\hline $\begin{array}{l}-43 \% \text { total emission reduction at emission } \\
\text { trading sectors } \\
\text {-Investment subsidies for renewable energy } \\
\text { production } \\
\text {-Compensation for electricity prices on } \\
\text { emission trading } \\
\text {-Coal phase-out by } 2030 \text { and } 50 \% \text { reduction of } \\
\text { oil import } \\
\text {-Promotion of pilot projects (subsidies) for the } \\
\text { introduction of new energy technologies } \\
\text {-Increasing production and technology for } \\
\text { biofuels and biogas } \\
\text {-Encouraging public sector to introduce } \\
\text { carbon-neutral energy solutions } \\
\text {-Taxation system reformation for low- } \\
\text { emission energy sources } \\
\text {-Energy regulations applicable to new } \\
\text { buildings for for form } \\
\text {-Continue support for biogas plant } \\
\text { Biogas production on farms or from } \\
\text { agricultural biomasses } \\
\text {-Consideration for new energy sources (large } \\
\text { heat pumps, solar and industrial waste heat) } \\
\text { for district heating }\end{array}$ & $\begin{array}{l}\text {-Hanasaari coal power plant shut down by } \\
2024 \\
\text {-A } 100 \% \text { biofuel based power plant } \\
\text { construction in Vuosaari } \\
\text {-Renovating Salmisaari power plant for } 40 \% \\
\text { wood-based fuel } \\
\text {-Closing of Salmisaari oil heating plant } \\
\text {-District heat use from Loviisa nuclear power } \\
\text { plant } \\
\text {-Increasing decentralized energy production } \\
\text { from solar, geothermal, wood burning } \\
\text { Construction of large heat pumps, } \\
\text {-Get rid of all fossil fuel by } 2050 \\
\text {-Co-firing of } 5 \text {-7 \% pellets with coal } \\
\text {-Harakka island-renewable energy path } \\
\text {-Solar power plants on the roofs of public } \\
\text { buildings } \\
\text {-Adding solar power through zoning and } \\
\text { information } \\
\text {-Increasing cleantech investments } \\
\text {-Promoting the introduction of geothermal } \\
\text { and renewable energy sources in new } \\
\text { construction } \\
\text {-Installation of solar equipment and air source } \\
\text { heat pump without permits } \\
\text {-Waste heat use from Neste Porvoo }\end{array}$ \\
\hline
\end{tabular}




\begin{tabular}{|l|l|}
\hline -Decentralized electricity and heat production & -New funding models such as Green Bonds \\
based on renewable energy, decentralized & $\begin{array}{l}\text { and Bulk Financing for renewable energy } \\
\text { small-scale production based on market terms } \\
\text { production }\end{array}$ \\
-Priority for investment subsidies for plants & $\begin{array}{l}-15 \% \text { electricity production with solar panels } \\
\text { producing biofuels for transport, use of } \\
\text { (City of Espoo) }\end{array}$ \\
electricity and heat producing companies and & of Espoo) \\
farms & \\
-No investment in new coal power plants and & \\
replacement & \\
-Energy taxation reforms for the use of forest & \\
chips and by-products & \\
Improvements to combustion technology for & \\
small-scale burning of woods & \\
\hline
\end{tabular}

Both the national and the City of Helsinki's aim is to shift from fossil to cleaner fuels (e.g. coal to natural gas or other renewable fuels) for energy production. They prioritize the use of bioenergy for the energy transition and feed-in tariff and incentives have been provided to promote bioenergy. Such incentives are also provided for wind. The country utilizes 68 TWh or 19\% nuclear energy mix (in 2016) for its final energy consumption (Tilastokeskus, 2017) and a small amount (1 632 GWh or 9.5\% of total energy mix) of nuclear energy (in 2014) has been utilized for electricity production also in the Helsinki Metropolitan area (Tilastokeskus, 2017).

The use of waste heat has also been stated in the energy policies of the City of Helsinki but has not implemented this policy yet. The experts in the City of Helsinki have also proposed financial measures (e.g. bulk financing and green bonds) but such decisions have not been made by the city yet. However, according to one respondent, the city council is likely to accept the proposed measures.

\section{Policies for energy utilization}

The majority of the heat and electricity produced is utilized in residential houses, transportation systems, and industries. Thus, appropriate policy measures are required for sustainable consumption of heat and electricity. The term 'energy utilization' differs from the term 'energy conservation' based on the location. Energy utilization is mainly 
performed at the end point of the energy systems and energy conservation can be done at any point of the energy systems. Table 2 presents energy policies for renewable energy utilization at the national level and in the City of Helsinki.

Table 2: Policy scenarios for energy utilization in Finland and Helsinki Metropolitan area (Ministry of economic affairs and employment, 2017; Helsingin kaupungin ympäristokeskus, 2015; Huuska et al., 2017; Parliamentary Committee on Energy and Climate, 2014)

\begin{tabular}{|c|c|}
\hline National level & Helsinki Metropolitan area \\
\hline $\begin{array}{l}\text {-Increasing the share of transport biofuels to } \\
30 \text { percent } \\
\text {-An obligation to blend light fuel oil used in } \\
\text { machinery and heating with } 10 \text { percent of bio- } \\
\text { liquids } \\
\text {-Use of } 250,000 \text { electric and } 50,000 \text { gas } \\
\text { powered vehicles on the roads by } 2030 \\
\text { - Horse manure utilization for energy } \\
\text { production } \\
\text {-Encouraging public sector to introduce } \\
\text { carbon-neutral energy solutions } \\
\text {-Sustainability criteria for the biomass energy } \\
\text { use } \\
\text {-Reducing utilization of oil for building } \\
\text { specific heating and machinery } \\
\text {-October energy week }\end{array}$ & $\begin{array}{l}\text {-Energy saving campaigns } \\
\text {-Promotional activities for local energy } \\
\text { production } \\
\text {-Smart small-scale production and utilization } \\
\text { of waste energies } \\
\text {-Reduction of oil consumption in buildings } \\
\text {-Switching to natural gas from oil } \\
\text { consumption } \\
\text {-Replacing oil heating with alternative low- } \\
\text { emission forms of production (land heating, } \\
\text { district heating, solar heating) } \\
\text { - Ilmastoinfo (awareness raising programme) }\end{array}$ \\
\hline
\end{tabular}

Promoting renewable energy utilization in buildings and transportation significantly reduces carbon emissions (Huang, Khanna, Önal, \& Chen, 2013; Chel \& Kaushik, 2017). Thus, both the national level and City of Helsinki's energy policies have emphasized electricity and clean fuel use in transportation system and in residential houses. Both have some programmes to raise the awareness about the utilization of clean energy in the buildings.

Policies for energy conservation and distribution 
Both the national and cities' energy policies include adequate energy efficiency measures for energy conservation but limited renewable energy promotion policies are available for these. Table 3 presents several energy policies for renewable energy conservation and distribution in both the national level and the City of Helsinki.

Table 3: Policy scenarios for energy conservation in Finland and Helsinki Metropolitan area (Ministry of economic affairs and employment, 2017; Helsingin kaupungin ympäristokeskus, 2015; Huuska et al., 2017; Parliamentary Committee on Energy and Climate, 2014)

\begin{tabular}{|l|l|}
\hline National level & Helsinki Metropolitan area \\
\hline -Promotion of electric vehicles & -Introduction of electric vehicles \\
-Promotion (subsidies) of pilot projects for the & $\begin{array}{l}\text {-Research and development for energy } \\
\text { storage batteries } \\
\text { introduction of new technologies } \\
\text {-Obligation to distribute transport biofuels }\end{array}$ \\
& Research and development for grids \\
\hline
\end{tabular}

The policies such as the introduction and promotion of electric vehicles (EVs) are envisioned but not yet implemented. EVs could act as energy storage systems for renewable electricity and providing subsidies for new projects related to research and development of energy-saving technologies. Similarly, policies related to distribution system of renewable energy are not yet in place, except the Research and Development project subsidies for grid development.

One respondent from Helen Limited thinks that the reason behind these developments is that 'Much of the technologies for intelligent grids and energy storage technologies need to be advanced through research and development projects'.

Another respondent expects that 'for the electricity vehicles policies, government is preparing to bring an attractive programme to encourage people to utilize EVs'.

Similarly, one respondent from a City of Espoo understands that 'The cities have just established new climate goals and are currently formulating the climate roadmaps to become carbon neutral. Thus, envisioned climate and renewable 
energy policies have not been formulated yet and they will be in the climate roadmaps after the city councils pass the climate roadmaps'.

The nature of the national energy policies and local level energy differ in terms of implementation and monitoring responsibilities. For instance, investment tax subsidies for renewable energy production is same for all cities in Finland and it is automatically included in the local level policies. However, how to utilize clean fuels in the power plants and whether to establish new bio plant or wind energy farms are dependent on local level policies. Both the Helsinki Metropolitan area and national level energy policies have prioritized renewable energy production (Helsingin kaupungin ympäristokeskus, 2015; Ministry of economic affairs and employment, 2017; Parliamentary Committee on Energy and Climate, 2014; Huuska et al., 2017). The climate policies of the City of Helsinki are more focused on emissions reduction through other methods, such as promotion of bicycle riding, parking management, LED street lighting installations as street lighting, mobility practices of the city employees, and increasing the share of public transportation. Such measures have already greatly impacted reducing significant carbon emissions (Helsingin kaupungin ympäristokeskus, 2015; Environmental Officer at the City of Helsinki, interview, 31.08.2017).

\subsection{Key shortcomings, barriers and solutions to implementation of renewable energy policies}

There are several political, technological, economic and societal barriers to formulate and implement the renewable energy policies and we use the MLP framework in this section to analyze the shortcomings and barriers and to identify innovative policy solutions to overcome the shortcomings and barriers. Several new renewable energy policy options and amendments to existing energy policy schemes can be identified to address the shortcomings of the renewable energy policies and overcoming the key barriers for the proper utilization of renewable energy sources. New solution measures are necessary during the commencement of energy transition solutions as the old solutions are either outdated or accomplished. In addition, changing circumstances for technology development, emission reduction and revised targets for energy production and consumption also demand innovative solutions. 


\subsubsection{Five different socio-technical regime interfaces}

a) Renewable energy dynamics

Formulation and implementation of renewable energy policies depend on various factors, such as composition of the carbon emissions generated from the various sectors, availability of renewable energy sources, circumstance of the technological development, implementation power of the administration, political commitments, availability of budgets and willingness of societal engagements. Major sectoral emissions production in the cities in the Helsinki Metropolitan area include $43.8 \%$ emissions from district heating (DH), $26.9 \%$ from transport, $25.4 \%$ from the use of electricity in 2015 (Helsinki Environment Centre, 2017). This means that renewable energy policies should impact on these sectors to significantly reduce carbon emissions. Major renewable energy sources available in Finland (Helsinki area) are wood chips, black liquor, solar power, ground source heat pump, wind energy, biofuels and bioliquids, biogas, and industrial wood residues (Statistics of Finland, 2016) (Helen Limited employee, interview, 08.08.2017). Currently, used renewable energy sources in Helsinki Metropolitan area are bioenergy, waste energy and small scales of solar, geothermal and heat pumps.

Several energy policies, such as energy and carbon taxes, investment subsidies, feed-in tariff, awareness raising programmes and societal engagement determine how these renewable energy sources will be utilized to reduce carbon emissions. Almost all marketed renewable energy technologies are available in Finland (Helen Limited employee, interview, 11.08.2017; Vantaan Energia employee, interview, 08.08.2017; Aslani, Helo, \& Naaranoja, 2013). The power of the cities to implement policy is dependent on the political commitments and administrative cooperation. Political commitments toward carbon neutrality in all cities in the Helsinki Metropolitan area are ambitious (Climate officer at HSY, interview, 29.08.2017) but the cities lack proper roadmaps to carbon neutrality as they have just started to work on the formulation of roadmaps.

Both the national and cities' current energy policies do not strongly support small-scale renewable energy production. For instance; investment subsidies are not available for small-scale solar energy in Finland (Dahal, Niemelä, \& Juhola, 2017). Similarly, the cities 
in Helsinki Metropolitan area have no strong policies for integrating renewable energy (waste heat, heat pumps, solar) in the buildings and district heat network (Researcher at Finnish Environmental Institute, interview, 24.08.2017; Climate officer at HSY, interview, 29.08.2017). The industrial waste heat and biogas utilization solutions are not strategic due to the lack of proper guidelines and policies from the cities. The City of Helsinki plans to increase renewable energy production to $20 \%$ by 2020 but how much targets should be achieved from the different renewable energy sources, such as solar and heat pumps have not been defined.

The metropolitan region possesses plentiful possibilities to produce energy from renewable energy resources but feasibilities of some renewable energy resources are not yet studied. For instance, both onshore and offshore wind power production is possible around the Helsinki Metropolitan area and recent study reveals that peoples' perception towards wind power production in this region is increasingly being positive (Jung et al., 2016). Yet, the cities do not produce wind energy due to lack of feasibility study (Vantaan Energia employee, interview, 08.08.2017). However, the City of Helsinki is working for the feasibility study for the wind power production within its boundary (Environmental Officer at the City of Helsinki, interview, 31.08.2017; Huuska et al., 2017). Although energy production from ground source heat pumps (GSHP) is growing in two of the cities, they have quite difficult procedures for issuing permits. Similarly, larger capacity of geothermal energy production may also be feasible in Helsinki area but this has not been confirmed yet and one pilot project for geothermal energy production is underway in the City of Espoo (Environmental Officer at the City of Helsinki, interview, 31.08.2017).

All the renewable energy policies in Table 4 are important for renewable energy production. For instance, the cities have not used enough renewable energy in their final energy consumption. Currently, utilization of some renewable energy technologies (e.g. solar, geothermal and wind power technologies) are in their infancy in Helsinki Metropolitan area. Except for several renewable energy plants such as the waste energy plant in Vantaa, several heat pumps in Espoo, and some solar plants in all cities, other renewable energy plants do not exist in this region. Thus, the cities should encourage both small-scale decentralized and large-scale centralized renewable energy technologies (onshore wind, solar-PV, biogas, heat pumps, biomass plants). 


\section{b) Organizational dynamics}

Organizational structures of the city departments, working patterns and practices, and political environment of the cities greatly impact the formulation and implementation of robust renewable policies. Administrative capabilities of the cities play a crucial role in implementing existing renewable policies and innovative and effective policies. The cities suffer from some administrative obstacles as regards carbon neutrality. For instance, Espoo and Vantaa lack sufficient officials to work for the climate and energy policies. Poor co-operation between the city departments in some cities has also affected climate and energy action and plans. Respondents from two cities agree that their citizens are not well informed about the profitability of the renewable energy production. This is because these cities do not have enough resources to disseminate such information to the residents (Environmental Officer at the City of Espoo, interview, 31.08.2017; (Environmental Officer at City of Kauniainen, interview, 06.10.2017). Similarly, some administrative procedures for small-scale renewable energy production are quite difficult. For instance, permissions required for solar plants installation in old buildings can be a difficult procedure.

Structures of the city administrations play a crucial role when formulating energy policies. For instance, the cities do not have separate and well institutionalized environmental departments to work for the environmental solutions. Except for the City of Helsinki, other cities consist one to three officials and they get multiple responsibilities together with the environmental solutions Environmental Officer at the City of Espoo, interview, 31.08.2017; Environmental Officer at City of Vantaa, interview, 13.09.2017). Personnel at the environmental departments of two cities also endure problems to communicate with the top management level personnel.

The cities can formulate and implement various innovative renewable collaborations with other cities, businesses and research. Participatory decision-making processes, such as the involvement of citizens, public and private institutions and investors, and nongovernmental organizations and communities to formulate and implement renewable energy policies for climate works are also very important for the carbon neutrality (Climate officer at HSY, interview, 29.08.2017; Environmental Officer at City of Helsinki, interview, 31.08.2017). Thus, cities can invite them to participate in the carbon emissions reduction decision-making processes. For instance, inviting housing companies' owners 
to participate in the climate and energy strategy formulation and implementation programs can help construction and retrofit of climate-friendly and renewable energy integrated buildings.

c) Infrastructure dynamics

Physical infrastructures, such as electrical grids, heat networks, power plant furnaces, energy storage systems, electricity charging stations are the fundamental facilities for the establishment of renewable energy technologies. The citizens have difficulties in adopting electric vehicles in the present accessibility of the charging stations (Researcher at Finnish Environmental Institute, interview, 24.08.2017). Similarly, the modification for the furnaces/boilers in the power plants for biofuel co-firing is quite challenging. In addition, the CHP power companies are the modification for the furnaces/boilers in the power plants for biofuel co-firing is quite challenging which is not considered sustainable due to the carbon emissions produced during long-distance transportation (Helen Limited employee, interview, 11.08.2017). Furthermore, replacing coal with clean and renewable fuel is challenging because constructing of new biofuel power plants or modifying fuel beds in the power plant boilers cost high (Helen Limited employee, interview, 11.08.2017). Electric and heat networks for central energy systems are quite well established but accessibility of the local heat and electricity networks for small-scale renewable energy production is a challenge for this moment. Also, the power plants have limited energy storage stations with small capacities. Thus, innovative energy policies are required to solve these problems.

The development of local electricity and heat network is essential for the small-scale renewable energy utilization in public and private buildings. In addition, the use of energy storage batteries for both the small scale and large scale renewable energy production are important because renewable energies are a fluctuating source of electricity generation. Similarly, an increase in electric vehicle charging stations is required for the introduction of electric vehicles. In both the cases, financial incentives are also important in the initial phase of development. The cities' primary work is to formulate effective policies for the development of these infrastructures.

d) Economics and user policies dynamics

The cities lack strong financial policies and business models for renewable energy development. Appropriate new technologies for Finnish condition, such as solar and heat 
pumps, require strong business policies to emerge into the local energy markets. Energy prices for small-scale renewable energy are quite high at the moment and encouraging financial measures are quite poor in these cities.

Distribution of budgets for carbon neutrality in the City of Helsinki is sufficient (Environmental officer at the City of Helsinki, interview, 31.08.2017) but Espoo and Vantaa lack sufficient budgets for climate policies. The cities have competence to access the central government's financial aids for implementing renewable energy utilization. Monopoly in the grid market is also a barrier to competitive energy distribution, which has also made obstacle to selling decentralized and small-scale renewable energy production.

The cities can bring supportive financial measures and business models, such as subsidies to renewable energy production, easy loan access for the construction of renewable energy plants, and increasing budgets for renewable energy development in the region. For instance; Germany and several cities in California and Colorado in USA have implemented such financial measures for the promotion of renewable energy (Dahal,Niemelä, \& Juhola, 2017). However, investment subsidies are also available for certain larger scale renewable energy production in the cities in Helsinki Metropolitan area (MEAE, 2018). These cities can also ease the grid monopoly to comfort the energy market (Dahal,Niemelä, \& Juhola, 2017). New economic policies for renewable energy promotion can include policies to alter the current state of renewable energy via institutional entrepreneurship.

e) Socio-cultural dynamics

Socio-cultural dynamics play a crucial role to development of renewable energy and achievement of carbon neutrality because actions of the various societal groups such as local residents, media, city authorities, political parties, advisory bodies and government ministries are guided by beliefs, conflicting values, competing interests, unequal resources, and complex social relations (Farla et al., 2012; Geels et al., 2017). Various city departments, environmental authorities in the region, research institutions and universities, housing companies and other energy-related businesses, and local residents contribute to the realization of carbon neutrality and utilization of renewable energy resources (Dahal, Niemelä \& Juhola, 2017; Environmental Officer at the City of Helsinki, interview, 31.08.2017; Researcher at Finnish Environmental Institute, interview, 
24.08.2017; Climate officer at HSY, interview, 29.08.2017). They are also responsible actors for energy production, utilization, distribution, and conservation. Low carbon transitions to carbon neutrality are not only the market diffusion of new technologies but also about the changes in beliefs and practices, cultural discourses and political struggles (Geels, et.al., 2017).

Social acceptance, cost-effectiveness, political feasibility, and resilience of the renewable energy technologies are crucial for promoting renewable energy. Societal perception towards renewable energy can alter some city policies. Some of the renewable energy technologies (e.g. wind energy) are still not accepted by all the residents (Jung et al., 2016). The current high price of the renewable electricity is also not feasible to invest in these sources. Demographic distribution of the cities can also affect renewable energy policies. Population in the cities in Helsinki Metropolitan area is growing. For instance; in reference to the population 2016, 200000 more people will be in the City of Helsinki by 2035 (Huuska et al., 2017). This means current renewable energy policies should be modified to address the population growth.

An integrated approach of various societal groups (actors) towards searching, learning, collaborating, moves, countermoves for the renewable energy development is essential. While formulating and implementing the new energy policies, it is crucial to consider whether the public can accept or reject the policy changes. Citizens' wider spread political support for the new policies is essential (Geels, 2014). Similarly, the cities can bring various public attitude changing and informative programmes for the development of renewable energy.

To expand on the above discussion, we list various additional energy policies in relation to five socio-technical regimes in Table 4 which support for the renewable energy utilization. These lists are additional energy solutions for the cities to their existed energy policies, which were collected from various documents and interviews. The categories are the same as five socio-technical regimes of MLP because these policy implications are for the cities.

Table 4: Policy schemes to promote renewable energy utilization in Helsinki Metropolitan area

\begin{tabular}{|l|l|l|l|l|}
\hline $\begin{array}{l}\text { Infrastructure } \\
\text { development } \\
\text { dynamics }\end{array}$ & $\begin{array}{l}\text { Renewable energy } \\
\text { dynamics }\end{array}$ & $\begin{array}{l}\text { Organizational } \\
\text { dynamics }\end{array}$ & $\begin{array}{l}\text { Socio-cultural } \\
\text { dynamics }\end{array}$ & $\begin{array}{l}\text { Economics \& } \\
\text { user policies } \\
\text { dynamics }\end{array}$ \\
\hline
\end{tabular}




\begin{tabular}{|c|c|c|c|c|}
\hline $\begin{array}{l}\text { - Smart towns } \\
\text { with } 100 \% \\
\text { renewable } \\
\text { energy } \\
\text { systems } \\
\text {-Extension of } \\
\text { railways, } \\
\text { trams and } \\
\text { metro lines } \\
\text {-New } \\
\text { construction } \\
\text { for bio, geo, } \\
\text { and waste to } \\
\text { energy plants } \\
\text {-Extension } \\
\text { and } \\
\text { renovation of } \\
\text { DH network } \\
\text { for renewable } \\
\text { energy } \\
\text { integration } \\
\text {-Development } \\
\text { and utilization } \\
\text { of energy } \\
\text { storage } \\
\text { batteries and } \\
\text { other building } \\
\text { automation } \\
\text { systems } \\
\text {-Expansion of } \\
\text { charging } \\
\text { stations foctric } \\
\text { vehicles }\end{array}$ & $\begin{array}{l}\text {-Prioritization for } \\
\text { decentralized and } \\
\text { small-scale } \\
\text { renewable energy } \\
\text { production } \\
\text {-Large-scale wind } \\
\text { and geothermal } \\
\text { energy production } \\
\text {-Increasing heat } \\
\text { pump utilization in } \\
\text { buildings } \\
\text {-Use of waste heat } \\
\text { and biogas to district } \\
\text { heating } \\
\text {-Utilization of blend } \\
\text { fuels in transport } \\
\text { and power plants } \\
\text {-Reformation to } \\
\text { energy taxes } \\
\text { - Penalizing and } \\
\text { taxing emissions } \\
\text { - Incentives for fuel } \\
\text { changes } \\
\text {-More andards } \\
\text { utilization } \\
\text { building integrated } \\
\text { energy technologies } \\
\text {-Green certification } \\
\text {-Coding for energy } \\
\text { performance }\end{array}$ & $\begin{array}{l}\text {-Regional } \\
\text { co-operation } \\
\text { (e.g. between the } \\
\text { cities) } \\
\text {-Collaboration } \\
\text { with businesses, } \\
\text { institutes \& } \\
\text { industries } \\
\text {-Energy } \\
\text { cooperatives, or } \\
\text { community } \\
\text { sustainability } \\
\text { initiatives } \\
\text { - Coalitions with } \\
\text { other cities } \\
\text {-Political } \\
\text { support for the } \\
\text { promotion of } \\
\text { renewable } \\
\text { energy }\end{array}$ & $\begin{array}{l}\text { - Establishments } \\
\text { of pilot projects } \\
\text {-Consultations } \\
\text { and advice } \\
\text { services for } \\
\text { small-scale } \\
\text { renewable } \\
\text { energy } \\
\text { production } \\
\text {-Public debates } \\
\text { and leadership } \\
\text { programmes for } \\
\text { renewable } \\
\text { energy } \\
\text { promotion } \\
\text { - Campaigns \& } \\
\text { collecting } \\
\text { signatures } \\
\text {-Seminars \& } \\
\text { webinars for } \\
\text { information } \\
\text { sharing } \\
\text {-Use of medias } \\
\text { for clean energy } \\
\text { promotion } \\
\text {-Advertising } \\
\text { large number of } \\
\text { posters } \\
\text { throughout the } \\
\text { city } \\
\text {-Inclusion } \\
\text { study }\end{array}$ & $\begin{array}{l}\text { energy } \\
\text { production, } \\
\text { utilization, } \\
\text { distribution, } \\
\text { and } \\
\text { conservation } \\
\text {-Worthy } \\
\text { financial } \\
\text { measures such } \\
\text { as easy loans } \\
\text { from banks, } \\
\text { capital grants, } \\
\text { and subsidies } \\
\text { for renewable } \\
\text { energy the } \\
\text { production } \\
\text {-Increasing } \\
\text { budgets for } \\
\text { renewable } \\
\text { energy } \\
\text { development } \\
\text {-Competitive } \\
\text { business } \\
\text { models } \\
\text { promoting } \\
\text { decentralized } \\
\text { energy systems } \\
\text {-Establishment } \\
\text { of green bonds } \\
\text { for } \\
\text { investment to }\end{array}$ \\
\hline
\end{tabular}




\begin{tabular}{|c|c|c|c|}
\hline $\begin{array}{l}\text {-Utilization of } \\
\text { hybrid } \\
\text { vehicles } \\
\text { - Utilization of } \\
\text { tunnel } \\
\text { thermal heat } \\
\text { - New } \\
\text { solutions for } \\
\text { long-term } \\
\text { energy storage } \\
\text {-Network } \\
\text { development } \\
\text { for waste heat } \\
\text { and biogas } \\
\text { utilization } \\
\text {-Renovation } \\
\text { for renewable } \\
\text { energy } \\
\text { integration to } \\
\text { old buildings }\end{array}$ & $\begin{array}{l}\text {-Subsidies for } \\
\text { hybrid \& electric } \\
\text { vehicles as well as } \\
\text { charging stations } \\
\text {-Collection and } \\
\text { utilization of landfill } \\
\text { gases and recycle } \\
\text { fuels } \\
\text {-Adding municipal } \\
\text { subsidies for } \\
\text { renewable energy } \\
\text {-Hybrid solar } \\
\text { heating system } \\
\text {-Carbon neutral } \\
\text { transportation } \\
\text {-Small renewable } \\
\text { energy integration } \\
\text { to district heating } \\
\text { (DH) }\end{array}$ & $\begin{array}{l}\text { energy systems } \\
\text { in school } \\
\text { curriculum } \\
\text {-Organizing } \\
\text { evening } \\
\text { meetings } \\
\text {-Organizing } \\
\text { public debates, } \\
\text { campaigning on } \\
\text { the streets for } \\
\text { the support of } \\
\text { citizens, } \\
\text {-Participatory } \\
\text { decision- } \\
\text { making policy } \\
\text {-Expert } \\
\text { interviews, } \\
\text { design } \\
\text { workshops }\end{array}$ & $\begin{array}{l}\text { renewable } \\
\text { energy and } \\
\text { clean fuels } \\
\text {-Increasing the } \\
\text { levels of current } \\
\text { subsidies } \\
\text {-Feed-in } \\
\text { premium for } \\
\text { renewable } \\
\text { energy } \\
\text { production } \\
\text {-Eco-efficiency } \\
\text { improvement }\end{array}$ \\
\hline
\end{tabular}

Some of these strategies are already formulated and being implemented in the City of Helsinki, while others are still to be formulated both at the national level and in the cities in the Helsinki Metropolitan area. For instance, street campaigns for climate measures and some collaborative seminars and workshops for climate works but such actions are not much frequent in the cities at the moment. Such strategies have already greatly impacted emission reduction and climate neutrality. However, Espoo, Vantaa and Kauniainen lack most of these strategies and they can include these for their planned climate roadmaps to carbon neutrality.

\subsubsection{Renewable niche innovation}

The stated socio-technical perspective of renewable energy policy options enables a breakthrough of emerging renewable technologies in the Finnish energy markets. However, this is only possible if the city governments provide financial incentives to investors, bring innovative business models, offer administrative support, and develop 
necessary infrastructures for the establishment of the emerging technologies, such as solar thermal and heat pumps. Social acceptance of wind and solar energy is still largely negative although some people have started solar energy production in this area (Jung et al., 2016; Dahal,Niemelä, \& Juhola, 2017).

Commercial motivations and regulatory compliance are the major drivers for renewable energy niche deployment (Geels et al., 2016; Miera, 2010). Renewable energy deployment is mainly enacted by energy companies and professional solar businesses in the Helsinki Metropolitan area. Renewable energy policies should focus on incentivizing these actors as well as attract new entrants to the renewable energy businesses.

In the current situation, some of the recent renewable technologies (e.g. solar and geothermal) cannot immediately compete in the energy market with other technologies. Providing attractive financial incentives for both larger and smaller renewable energy production will be supporting niche development. The cities can formulate clear renewable policies (e.g. solar-PV strategy, wind energy strategy, and geothermal energy strategy) in collaboration with the various renewable energy businesses, consulting groups and real estate companies. For this, the cities can scope out their current prospects and future need for the energy consumption and renewable energy production in their geographical boundaries. Such policies should be able to address the current issues on the renewable energy production, consumption, and distribution.

Energy companies, businesses and the cities can collaborate to form and implement the appropriate renewable energy policies. This helps city administrations to adopt the ideas and interest of such energy and business organizations. The cities can also adopt free energy and grid market policies and pressure the companies to implement strong corporate responsibility policies. This helps to enhance the small-scale renewable energy production and reduce the obstacles due to monopoly of the energy grids. Demonstration projects can be set up so that the companies can gain experiences and residents can learn about the benefits of the renewable energy sources. The most important point is that the renewable niche innovation is possible only by collective enactment and inclusion of all the societal groups.

\section{Discussion and conclusion}

Our findings show that current renewable energy policies for carbon neutrality in the Helsinki Metropolitan area are weak but many options are available for improvements 
to current policies. We also found that national renewable energy policies are looking more constructive and advanced than the energy policies in the cities in the Helsinki Metropolitan area (See tables). However, many of the national renewable energy policies are also deployed in the cities in the Helsinki Metropolitan area and their roles to achieving the carbon neutral goals of the cities are vital. Both national and local level energy policies have been implemented to some extent in these cities. Yet, the cities have to work a lot more for the realization of these policies and formulation of renewable energy policies for the short-term and long-term future plans. Within the energy transition context of the cities, this study shows that renewable energy policies for sociocultural, infrastructural, techno-economical, and institutional transitions play important role to low carbon energy transition to carbon neutrality (IEA \& IRENA, 2017; Poggi, Firmino, \& Amado, 2017; Verbong \& Geels, 2007) but current renewable energy policies need to be amended to achieve the carbon neutral target.

With regard to national level low-carbon energy transition, resilience of renewable energy regime is positive towards the energy generation from the renewable sources while the local level low-carbon energy transition in Helsinki Metropolitan area has just started to take off and utilization of renewable sources are at infancy stage. However, these local practices will be helpful not only to achieve carbon neutrality but also to reduce carbon emissions at the national level (Petersen, 2016). The current renewable energy investment landscape in the cities is not moving fast enough in the right direction and requires renewable energy promoting investment decisions and with robust short and long-term energy policy implications (Laes, Gorissen, \& Nevens, 2014; Voß, Smith, \& Grin, 2009; Nevens \& Roorda, 2013). Cities and government can bring attractive business models, such as mortgages or securing home equity lines of credit, and acquiring personal loans and financial incentives to promote renewable energy (Fuller et al.; 2009). The cities can utilize all available renewable energy resources to achieve their renewable energy targets and carbon neutral goals. This will also increase the energy security of the city (Hiteva, 2013).

The discussion of carbon neutrality should not just focus on promoting renewable energy but also on preventing the use of fossil-fuel and non-renewable energy sources and adoption of carbon capture and sequestration (CCS) (Geels, 2014). In fact, destabilization of carbon-emitting energy sources helps to promote renewable energy. The cities should 
establish solid regional cooperation, especially among the four metropolitan cities. The cooperation between the cities and private investors and businesses is also vital for implementing climate and energy plans (Dahal, Niemelä \& Juhola, 2017; Laes, Gorissen, \& Nevens, 2014). In addition, strong political commitments from the different political parties within the city councils are critical (Dahal \& Niemelä, 2016). To accomplish the goal, the cities also require innovative policies to engage various stakeholders in their decision-making processes, climate works and projects to promote renewable energy production and consumption. The cities should look at the multi-level perspective (technical, regulatory, economic, and cultural) approaches to their current energy transitions towards renewable energy development and establish carbon neutrality (Geels, 2011; Laes; Gorissen, \& Nevens, 2014). A full-scale and carbon neutrality and energy transition in the cities will increasingly require coordinated approach at city level and beyond. This implies the cooperation between the businesses, national and city governments, various institutions and civil society at broad scale (Laes, Gorissen, \& Nevens, 2014). This study provides insights for the national and local authorities to prioritize local energy production for the security of energy supply.

Acknowledgments: We would like to thank all the interviewees who provided their time and useful data for this research work. We would also like to thank editor and anonymous reviewers for their constructive comments and suggestions to improve the quality of this paper.

Author Contributions: Karna Dahal collected the data, performed the analyses and drafted the manuscript, Associate Professor Sirkku Juhola edited, guided, and commented on the manuscript, and Professor Jari Niemelä provided supervision of all stages, edited, guided, and commented on the manuscript.

Conflicts of Interest: The authors declare no conflict of interest.

Funding: This research did not receive any direct grant from funding agencies in the public, commercial, or not-for-profit sectors.

\section{References}


1. Agostani, A., Giuntoli, J., \& Boulamanti, A. (2014). Carbon accounting of forest bioenergy. European Commission, Joint Research Centre, Institute of Energy and Transport. Luxembourg: European Joint Research Centre.

2. Aslani, A., Helo, P., \& Naaranoja, M. (2013). Role of renewable energy policies in energy dependency in Finland: System dynamics approach. Applied energy, 113, 758-765.

3. Bach, B., Werling, J., Ommen, T., Münster, M., Morales, J. M., \& Elmegaard, B. (2016). Integration of large-scale heat pumps in the district heating systems of Greater Copenhagen. Energy, 107, 321-334.

4. BBC news. (2017, 07 26). New diesel and petrol vehicles to be banned from 2040 in UK. Retrieved 11 10, 2017, from BBC NEWS website: http://www.bbc.com/news/uk-40723581

5. Brandt, N., Cambell, F., Deakin, M., \& Holmstedt, L. (2014). European Cities Moving Towards Climate Neutrality Participation, Indicators and Benchmarking. Stockholm: CLUE - Climate Neutral Urban Districts in Europe. DOI: 10.13140/2.1.3166.3369

6. Chel, A., \& Kaushik, G. (2017). Renewable energy technologies for sustainable development of energy efficient building. Alexandria Engineering Journal.

7. City of Espoo. (2017). Climate goals aim for carbon neutrality. Retrieved 1109 , 2017, from City of Espoo's official website: http://www.espoo.fi/enUS/Housing_and_environment/Sustainable_development/Climate_goals.

8. Corfee-Morlot, J., Kamal-Chaoui, L., Donovan, M. G., Cochran, I., Robert , A., \& Teasdale, P. J. (2009). Cities, Climate Change and Multilevel Governance. OECD. Paris: OECD Publishing.

9. Dahal, K., \& Niemelä, J. (2016). Initiatives towards Carbon Neutrality in the Helsinki Metropolitan Area. Climate, 4(3), 36. doi:10.3390/cli4030036

10. Dahal, K., \& Niemelä, J. (2016). Cities' Greenhouse Gas Accounting Methods: A Study of Helsinki, Stockholm, and Copenhagen. Climate, 5(31).

11. Dahal, K., Niemelä, J., \& Juhola, S. (2017). The role of solar energy for carbon neutrality for Helsinki Metropolitan area.

12. Dorn, A. V. (2017, 84 ). Diesel and petrol cars to be banned by 2040. Respiratory Medicine, 5(9), 684-684.

13. Farla, J., Markard, J., Raven, R., \& Coenen, L. (2012). Sustainability transitions in the making: A closer look at actors, strategies and resources. Technological Forecasting \& Social Change.

14. Fuller, M. C., Portis, S. C., \& Kammen, D. M. (2009). Towards a low-carbon economy: Municipal financing for energy efficiency and solar power. Environment: Science and Policy for Sustainable Development, 51(1), 22-33.

15. Garfield, L. (2015, 10 20). Oslo just declared that it will become the first major city to ban cars. Retrieved 11 10, 2017, from Busi Insider webpage: 
www.businessinsider.com/oslo-bans-cars-from-its-city-center-2015$10 ? \mathrm{r}=\mathrm{US} \& \mathrm{IR}=\mathrm{T} \& \mathrm{IR}=\mathrm{T}$

16. Geels, F. W. (2011). The multi-level perspective on sustainability transitions: Responses to seven criticisms. Environmental Innovation and Societal Transitions, 1, 24-40.

17. Geels, F. W. (2014). Regime Resistance against Low-Carbon Transitions: Introducing Politics and Power into the Multi-Level Perspective. Theory, Culture \& Society, 31(5), 21-40.

18. Geels, F. W., Berkhout, F., \& Vuuren, D. P. (2016). Bridging analytical approaches for low-carbon transitions. Nature climate change, 576-583.

19. Geels, F. W., Kern, F., Fuchs, G., Hinderer, N., Kungl, G., Mylan, J., . . . Wassermann, S. (2016). The enactment of socio-technical transition pathways: A reformulated typology and a comparative multi-level analysis of the German and UK low-carbon electricity transitions (1990-2014). 45(4), 896-913.

20. Geels, F. W., Sovacool, B. K., Schwanen, T., \& Sorrell, S. (2017). The Socio-Technical Dynamics of Low-Carbon Transitions. Joule, 463-479.

21. Helsingin kaupungin ympäristokeskus. (2015). Helsinki's Climate Roadmap. Retrieved from https://issuu.com/helsinginymparistokeskus/docs/helsinki_climate_roadmap_201 50427

22. Helsinki Environment Centre. (2017). Helsinki Environment statistics. Retrieved 10 2, 2017, from Helsinki Environment statistics webpage: http://www.helsinginymparistotilasto.fi/

23. Helsinki Environmental Statistics. (2017). Helenin, Vantaan Energian ja Fortum Espoon sähkön ja kaukolämmön hankinta energialähteittäin 2002-2016. Retrieved from Helsinki Environmental Statistics: http://www.helsinginymparistotilasto.fi/

24. Hiteva, R. P. (2013). Fuel poverty and vulnerability in the EU low-carbon transition: the case of renewable electricity. Local Environment-The International Journal of Justice and Sustainability, 18(4), 487-505.

25. Huang, H., Khanna, M., Önal, H., \& Chen, X. (2013). Stacking low carbon policies on the renewable fuels standard: Economic and greenhouse gas implications. Energy Policy, 56, 5-15.

26. Huuska, P., Lounasheimo, J., Jarkko, M., Viinanen, J., \& Ignatius, S.-M. (2017). Selvitys Helsingin uusista ilmastotavoitteista. City of Helsinki Environmental Centre. Helsinki: Helsingin kaupungin ympäristökeskus.

27. IEA \& IRENA. (2017). Perspectives for the energy transition - investment needs for a low-carbon energy system. International Renewable Energy Agency (IRENA). 
28. IEA. (2009). Cities, towns \& Renewable energy. Yes In My Front Yard. . Organisation for Economic Co-operation and Development (OECD) and International Energy Agency (IEA). Paris: International Energy Agency.

29. IEA. (2013). Energy Policies of IEA Countries: Finland 2013. Paris: OECD iLibrary. doi: http://dx.doi.org/10.1787/19900082

30. Jung, N., Moula, M. E., Fang, T., Hamdy, M., \& Lahdelma, R. (2016). Social acceptance of renewable energy technologies for buildings in the Helsinki Metropolitan Area of Finland. Renewable energy, 99, 813-824.

31. Kivimaa, P., \& Kern, F. (2016). Creative destruction or mere niche support? Innovation policy mixes for sustainability transitions. Research Policy, 45(1), 205217.

32. Korhonen, K., Sokka, L., Salminen, O., Sievänen, R., Pingoud, K., Livesniemi, H., Sipilä, K. (2015). Sustainability of forest energy in Northern Europe. VTT Technical Research Centre of Finland Ltd. Espoo: VTT Technical Research Centre of Finland Ltd.

33. Kuckshinrichs, W., \& Hake, J.-F. (Eds.). (2015). Carbon Capture, Storage and Use (1 ed.). Springer International Publishing.

34. Kyne, D., \& Bolin, B. (2016). Emerging Environmental Justice Issues in Nuclear Power and Radioactive Contamination. (J. Chakraborty, S. E. Grineski, \& T. W. Collins, Eds.) International Journal of Environmental Research and Public Health, 13(7), 700.

35. Laes, E., Gorissen, L., \& Nevens, F. (2014). A Comparison of Energy Transition Governance in Germany, The Netherlands and the United Kingdom. Sustainability, 6, 1129-1152.

36. Lemon, M., Pollitt, M. G., \& Steer, S. (2015). Local energy policy and managing low carbon transition: The case of Leicester, UK. Energy strategy reviews, 6, 57-63.

37. Manyika, J., Chui, M., Bughin, J., Dobbs, R., Bisson, P., \& Marrs, A. (2013). Disruptive technologies: Advances that will transform life, business, and the global economy. McKinsey Global Institute.

38. MEAE. (2018). Projects eligible for aid and maximum amount of aid. Retrived from Ministry of Economic Affairs and Employment's website: http://tem.fi/en/projectseligible-for-aid

39. Miera, G. S. (2010). Regulation as a key driver for renewable energy development: lessons from the Spanish case. Presentation. Venetia: Climate Policy Initiative.

40. Miller, C. A., Iles, A., \& Jones, C. F. (2013). The social dimensions of energy transitions. Science and Culture, 22(2).

41. Minea, V. (2015). Energy Performances of Geothermal Heat Pumps Operating in Cold Climates. Proceedings World Geothermal Congress 2015. Melbourne: Stanford University school of earth, energy \& environmental sciences. 
42. Ministry of economic affairs and employment. (2017). Government report on the national energy and climate strategy for 2030. Helsinki: Ministry of economic affairs and employment.

43. Nevens, F., \& Roorda, C. (2013). A climate of change: A transition approach for climate neutrality in the city of Ghent (Belgium). Sustainable Cities and Society, 10, 112-121.

44. Ninan, K. N., \& Inoue, M. (2017). Building a Climate Resilient Economy and Society: Challenges and Opportunities. Cheltenham and Northampton: Edward Elgar Publishing Limited.

45. Nykvist, B., \& Nilsson, M. (2015). Rapidly falling costs of battery packs for electric vehicles. Nature climate change, 5, 329-332.

46. Parliamentary Committee on Energy and Climate. (2014). Energy and Climate Roadmap 2050. Helsinki: Ministry of Employment and Economy.

47. Petersen, J.-P. (2016). Energy concepts for self-supplying communities based on local and renewable energy sources: A case study from northern Germany. Sustainable Cities and Society, 26, 1-8.

48. Poggi, F., Firmino, A., \& Amado, M. (2017). Assessing energy performances: A step toward energy efficiency at the municipal level. Sustainable Cities and Society, 33, 57-69.

49. Puigianer, L., Pérez-Fortes, M., \& Laínez-Aguirre, J. M. (2015, 06 12). Towards a Carbon-Neutral Energy Sector: Opportunities and Challenges of Coordinated Bioenergy Supply Chains-A PSE Approach. Energies, 8(6), 5613-5660.

50. Singh, A., Pant, D., \& Olsen, S. I. (Eds.). (2013). Life Cycle Assessment of Renewable Energy Sources. London: Springer Link.

51. Sovacool, B. K. (2017). Contestation, contingency, and justice in the Nordic lowcarbon energy transition. Energy Policy, 102, 569-582.

52. Statistics of Finland. (2016). Energy in Finland 2016. Retrieved 11 10, 2017, from Statistics of Finland website: http://www.stat.fi/tup/julkaisut/tiedostot/julkaisuluettelo/yene_efp_201600_2016 _15894_net.pdf

53. Taylor, M., Ralon, P., \& Ilas, A. (2016). The power to change: solar and wind cost reduction potential to 2025. International renewable energy agency (IRENA). International renewable energy agency (IRENA).

54. Tilastokeskus. (2017). Statistics of Finland's PX-web databases. Retrieved from Statistics of Finland: http://pxnet2.stat.fi/PXWeb/pxweb/en/StatFin/StatFin_ene_ehk/statfin_ehk_pxt _008.px/table/tableViewLayout1/?rxid=467992a8-78fb-419f-9eec-1aef7c8ca971

55. Timmons, D., Harris, J. M., \& Roach, B. (2014). The Economics of Renewable Energy. A GDAE Teaching Module on Social and Environmental Issues in Economics. Medford: Tufts University. 
56. Verbong, G., \& Geels, F. (2007). The ongoing energy transition: lessons from a socio-technical, multilevel analysis of the Dutch electricity system (1960-2004). Energy Policy, 35(2), 1025-1037.

57. Voß, J.-P., Smith, A., \& Grin, J. (2009). Designing long-term policy: rethinking transition management. Policy Sciences, 42(4), 275-302. 